\title{
Ammonium Inhibits Processing and Cytotoxicity of Reovirus, a Nonenveloped Virus
}

Eleftheria Maratos-Flier, Matthew J. Goodman, Alison H. Murray, and C. Ronald Kahn

Elliott P. Joslin Research Laboratory, Joslin Diabetes Center, Boston, Massachusetts 02215; and Department of Medicine,

Brigham and Women's Hospital, Harvard Medical School, Boston, Massachusetts 02115

\begin{abstract}
Successful viral infection involves a series of interactions between the virus and the host cell. The outcome of viral infection is, in fact, dependent on intact cellular function; it is required for viral binding, internalization, and uncoating. To determine the potential importance of lysosomal processing on the outcome of infection with a nonenveloped virus, we have studied the effects of $\mathrm{NH}_{4} \mathrm{Cl}$ on the course of reovirus infection on a beta-cell tumor in culture. Addition of $10 \mathrm{mM} \mathrm{NH}_{4} \mathrm{Cl}$ to the medium inhibited viral growth by $>\mathbf{8 0} \%$ and reduced toxic effects of the virus on cell viability, protein, and DNA synthesis by $30-45 \%$. In addition, synthesis of viral proteins was markedly decreased. Uptake of virus prelabeled with $\left[{ }^{35}\right.$ S]methionine was not affected by the ammonium; however, cleavage of $\mu 1 \mathrm{C}$, an outer capsid protein of the virus whose cleavage appears to be required for viral replication, was delayed. These results suggest that intracellular processing of reovirus is dependent on a lysosomal pathway and that disruption of this pathway can alter the course of viral infection.
\end{abstract}

\section{Introduction}

Penetration of viruses into cells requires intact cellular function. For many viruses, penetration is accomplished via endocytic pathways; subsequent fusion of the endosome with a lysosome leads to processing of the virus and release of replicative material either as free proteins and nucleic acids or as subviral particles (SVPs). ${ }^{1}$ The importance of this pathway in the processing of enveloped viruses, such as Semliki Forest virus, has been extensively studied $(1,2)$. In addition, lysosomotropic agents will inhibit normal viral processing and will alter the course of infection $(3,4)$. While nonenveloped viruses, such as reovirus, have been found morphologically associated with lysosomes, the potential role of lysosomal processing for this class of viruses is less clear. Addition of $\mathrm{NH}_{4} \mathrm{Cl}$, a lysosomotropic agent $(5,6)$, enhances the likelihood of the development of persistent rather than acute reovirus infection (7), but the mechanism of this effect is unknown.

Reovirus is a double-stranded RNA virus with a segmented genome and wide host range; there are three naturally occurring serotypes, designated as types 1,2 , and 3 (8). Type 1 , when

Address reprint requests to Dr. Maratos-Flier.

Received for publication 17 March 1986.

1. Abbreviations used in this paper: PFU, plaque-forming units; SVP, subviral particles.

J. Clin. Invest.

(c) The American Society for Clinical Investigation, Inc.

0021-9738/86/10/1003/05 $\$ 1.00$

Volume 78, October 1986, 1003-1007 injected into newborn mice, infects ependymal tissue and causes hydrocephalus (9), whereas type 3 infects neurons and causes a rapidly fatal encephalitis (10). Both types 1 and 3 reovirus can also infect cells of the endocrine pancreas and may cause diabetes (11-13). Type 1 also produces an autoimmune syndrome associated with growth retardation (14).

We recently examined the interaction of reovirus with RINm5F cells, a rat insulin-secreting cell line derived from a radiation-induced islet cell tumor $(15,16)$, and found that both types 1 and 3 reovirus will grow in these cells (17). To determine the possible role of lysosomal processing on the outcome of reovirus infection in these cells we have examined the effect of $\mathrm{NH}_{4} \mathrm{Cl}$ treatment on both viral growth and cellular function.

\section{Methods}

\section{Cell culture}

RINm5F cells were grown on $80-\mathrm{cm}^{2}$ flasks in Ham's F10 medium that was supplemented with $10 \%$ horse serum and $2.5 \%$ fetal calf serum. $3 \mathrm{~d}$ before initiation of experiments, cells were detached using trypsin and subcultured on 24-well multiculture dishes. $L$ cells were maintained in monolayer culture on $80-\mathrm{cm}^{2}$ tissue culture flasks in minimal essential medium that was supplemented with $5 \%$ fetal calf serum.

\section{Viral growth and labeling}

Stocks of type 1 reovirus were grown in mouse $L$ cells. To biosynthetically label reovirus with $\left[{ }^{35}\right.$ S $]$ methionine, $L$ cells were grown in monolayer on $150-\mathrm{cm}^{2}$ tissue culture flasks (NUNC; Vanguard International, Neptune, $\mathrm{NJ})$ to confluence and then infected with virus at an input multiplicity of 4 plaque-forming units (PFU)/cell. $2 \mathrm{~h}$ after infection, $1 \mathrm{mCi}$ of ${ }^{35}$ S $]$ methionine was added per flask in $20 \mathrm{ml}$ of culture media. $3 \mathrm{~d}$ after infection the cells had detached. Cells were collected by low speed centrifugation and solubilized in $0.1 \%$ deoxycholic acid. Cells were sonicated, lipids were extracted using trichlorotrifluoroethane, and the aqueous layer containing virus was centrifuged over a continuous $\mathrm{CsCl}$ gradient as has been previously described (18). Specific activity of labeled virus was 29.5 $\mu \mathrm{Ci} / \mathrm{mg}$ of virus $\left(6.4 \mu \mathrm{Ci} / 10^{10} \mathrm{PFU}\right)$.

\section{Effect of ammonium chloride on cell growth and cellular function}

RINm5F cells were infected with type 1 reovirus at an input multiplicity of 4 PFU/cell. 90 min after infection, fresh media was added to each well; cells designated control received unsupplemented medium while the experimental group received medium containing $10 \mathrm{mM} \mathrm{NH}_{4} \mathrm{Cl}$. At the indicated times, samples of RINm5F cells were assayed for protein content, protein synthesis, DNA synthesis, and viral titer as follows:

(a) Cell protein. Culture dishes were washed three times with phosphate-buffered saline (PBS) to remove nonadherent cells. Attached cells were solubilized in $0.1 \mathrm{~N} \mathrm{NaOH}$ and protein content per well was determined using the Bio-rad Protein Assay (Bio-Rad Laboratories, Richmond, CA). We have previously shown that protein content correlates linearly with the number of viable cells, since dead cells rapidly detach from the dish and are not assayed (17). Protein content per well ranged between 110 and $140 \mu \mathrm{g} /$ well and was unaffected by $3 \mathrm{~d}$ of ammonia treatment. 
(b) Protein synthesis. After three washes with $1 \mathrm{ml}$ of PBS, $0.1 \mu \mathrm{Ci}$ of $\left[{ }^{14} \mathrm{C}\right]$ leucine in $1 \mathrm{ml}$ of leucine-free medium was added to each well. Cells were incubated for $1 \mathrm{~h}$ at $37^{\circ} \mathrm{C}$, then washed three times with PBS and solubilized in $1.0 \mathrm{ml}$ of $0.1 \%$ sodium dodecyl sulfate (SDS). To determine the amount of leucine incorporated into protein, $0.5-\mathrm{ml}$ aliquots of cell lysate were added to $0.1 \mathrm{ml}$ of $100 \%$ trichloroacetic acid (TCA) and allowed to stand on ice for $10 \mathrm{~min}$. Samples were then filtered through fiberglass GF/C filters (Fisher Scientific Co., Medfield, MA) and the precipitates washed three times with $5 \mathrm{ml}$ of cold $5 \%$ TCA. The amount of acid-precipitable leucine was then determined by drying filters and counting in a LKB scintillation counter using 3a70b scintillant (Research Products International, Mt. Prospect, IL). The amount of $\left[{ }^{14} \mathrm{C}\right]$ leucine incorporated was corrected for protein content per well. ${ }^{14} \mathrm{C}$-incorporation ranged between 8,000 and $12,000 \mathrm{cpm} / 100 \mu \mathrm{g}$ protein in uninfected nonammonium exposed cells. Addition of ammonium to uninfected cells led to a $10-20 \%$ decrease in cpm of $\left[{ }^{14} \mathrm{C}\right]$ leucine incorporated. Therefore, data on infected cells not treated with ammonium is normalized to uninfected controls not treated with ammonium. Data on infected cells treated with ammonium is normalized to uninfected cells treated with ammonium.

(c) DNA synthesis. After a 1-h incubation of the cells with $1 \mu \mathrm{Ci}$ of $\left[{ }^{3} \mathrm{H}\right]$ thymidine, samples were processed as described in section $b$ above, and $\left[{ }^{3} \mathrm{H}\right]$ thymidine incorporated into DNA was normalized for protein content. Incorporation of $\left[{ }^{3} \mathrm{H}\right]$ thymidine ranged between $7,000-10,000$ $\mathrm{cpm} / 100 \mu \mathrm{g}$ in uninfected, nonammonium, treated cells and was unaffected by addition of ammonium chloride. For consistent handling of data, however, data was calculated as described in section $b$ above.

(d) Viral titer. The growth medium was aspirated and cells were lysed by freeze thawing three times. Viral titer was measured by plaque assay using $\mathrm{L}$ cell monolayers (19).

\section{Viral uptake and processing}

Purified, dialized, [ ${ }^{35}$ S]methionine-labeled virus $(30,000 \mathrm{cpm}$, equal to $\sim 4.2 \times 10^{7} \mathrm{PFU}$ ) was added to monolayers of RINm5F cells grown on 24-well plates. To add sufficient counts to analyze uptake and processing, it was necessary to infect cells at this high multiplicity. At designated intervals, monolayers were washed three times with PBS, solubilized in Laemmli buffer (20), and boiled: Uptake of labeled virus was determined by counting the amount of radioactivity in aliquots of solubilized cells in a scintillation counter. To assess processing, we subjected some samples to SDS-polyacrylamide gel electrophoresis, using $10 \%$ gels, followed by autoradiography of the gel.

\section{Viral protein synthesis}

RINm5F cells were infected with varying amounts of type 1 reovirus ranging between 0.4 and $10 \mathrm{PFU} / \mathrm{cell} ; 90 \mathrm{~min}$ after infection, growth medium, either with or without $10 \mathrm{mM}$ ammonium chloride or $10 \mu \mathrm{M}$ chloroquine, was added to each well. $48 \mathrm{~h}$ after infection, growth medium was aspirated and fresh methionine-free medium containing $2 \mu \mathrm{Ci}$ of ${ }^{35}$ S]methionine was added to each well. Cells were pulsed for $2 \mathrm{~h}$ at $37^{\circ} \mathrm{C}$ and then washed three times with cold PBS. Cells were then solubilized in Laemimll buffer and subjected to SDS-polyacrylamide gel electrophoresis using $10 \%$ gels, followed by autoradiography.

\section{Results}

Treatment of $\mathrm{RIN}$ cells infected with type 1 reovirus with $\mathrm{NH}_{4} \mathrm{Cl}$ caused a marked reduction in viral titer by $48 \mathrm{~h}$. Viral titer in infected ammonium-treated cells was $3.8 \times 10^{6}$, as compared with a titer of $1.9 \times 10^{7}$ in infected control cells (RINm5F cells infected but not treated with ammonium) (Fig. $1 d$ ). In four separate experiments, the decrease in viral tital in $\mathrm{NH}_{4} \mathrm{Cl}$-treated cells ranged from 50 to $90 \%$. This decrease in viral titer was associated with a reduction in cell kill (as assessed by protein content per well) at $48 \mathrm{~h}$ from $40 \%$ in infected control cells to $14 \%$ in ammonium-treated cells (Fig. $1 \mathrm{~A}$ ). Ammonium-treated
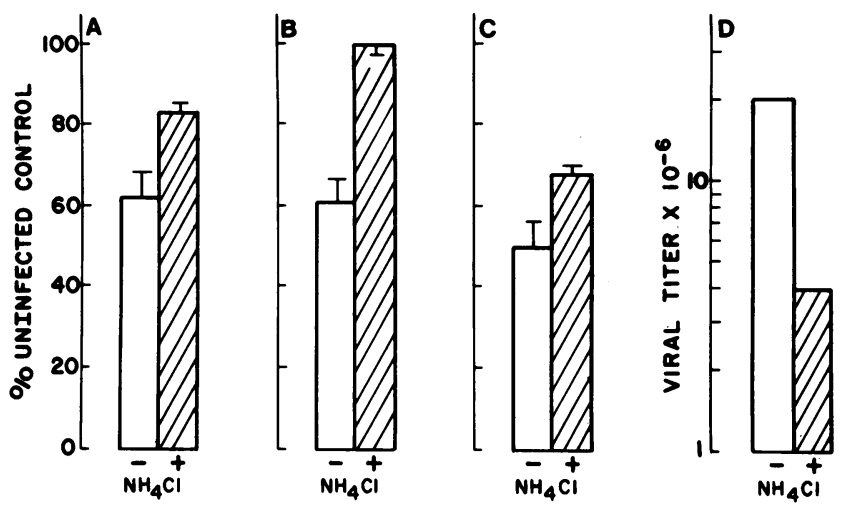

Figure 1. Cells grown on 24-well plates were infected with type 1 reovirus at an input multiplicity of 4 PFU/cell. $48 \mathrm{~h}$ after infection, cellular viability, effects on DNA and protein synthesis, and viral titer were determined. Each data point represents the mean of triplicate wells and error bars denote standard error. Similar results were obtained in at least separate experiments. $(A)$ Total protein per well. Protein content per well ranged between 110 and $140 \mu \mathrm{g}$ and cells unaffected by ammonium treatment. (B) Protein synthesis. Virally infected cells not treated with ammonium incorporated $6,876 \pm 170 \mathrm{cpm}$ of $\left[{ }^{14} \mathrm{C}\right]$ leucine/ $100 \mu \mathrm{g}$ protein. This was corrected to incorporation by uninfected control cells of $11,295 \pm 307 \mathrm{cpm} / 100 \mu \mathrm{g}$. Virally infected ammoniumtreated cells incorporated $8,735 \pm 202 \mathrm{cpm}$ of $\left[{ }^{14} \mathrm{C}\right]$ leucine/100 $\mu \mathrm{g}$ protein. This was corrected to a $\left[{ }^{14} \mathrm{C}\right]$ leucine incorporation by uninfected cells treated with ammonium that was $8,685 \pm 133 \mathrm{cpm} / 100 \mu \mathrm{g}$ protein. $(C)$ DNA synthesis. Virally infected cells not treated with ammonium incorporated $3,710 \pm 333 \mathrm{cpm} / 100 \mu \mathrm{g}$ protein of $\left[{ }^{3} \mathrm{H}\right]$ thymidine. This was corrected to incorporation by uninfected cells not treated with ammonium of $7,377 \pm 184 \mathrm{cpm}$. $(D)$ Viral titer. Virally infected cells treated with ammonium incorporated $6,026 \pm 297 \mathrm{cpm} / 100 \mu \mathrm{g}$ of $\left[{ }^{3} \mathrm{H}\right]$ thymidine. This was corrected to incorporation by uninfected cells treated with ammonium of $9,186 \pm 235 \mathrm{cpm} / 100 \mu \mathrm{g}$ protein.

cells also retained normal macromolecular synthesis when compared with infected untreated cells (Fig. $1, B$ and $C$ ). Thus, ammonium-treated cells showed no reduction in $\left[{ }^{14} \mathrm{C}\right]$ leucine incorporation into protein, whereas infected control cells showed a $40 \%$ reduction in protein synthesis, even when corrected for the decrease in cell number. Similarly, ammonium-treated cells showed only a $30 \%$ reduction in $\left[{ }^{3} \mathrm{H}\right]$ thymidine incorporation, whereas infected, untreated cells demonstrated a reduction of $50 \%$ or more when compared with uninfected cells.

To examine the effect of ammonium on viral protein synthesis, cells were infected with varying amounts of reovirus and pulse labeled after $48 \mathrm{~h}$ with $\left[{ }^{35} \mathrm{~S}\right]$ methionine, solubilized in Laemmli, and analyzed by SDS-polyacrylamide gel electrophoresis. Three classes of viral proteins, designated $\lambda, \mu$, and $\sigma$, could be identified (Fig. 2). The intensity of labeling of these viral bands was dependent on the infectious dose of virus added. Ammonium chloride treatment $(10 \mathrm{mM})$ inhibited the labeling of the viral bands at all infectious doses. This effect was most notable at infecting multiplicities of 0.4 and 1 PFU/cell but was also present at 4 and $10 \mathrm{PFU} / \mathrm{cell}$. These higher multiplicities of viral infection are associated with significant inhibition of cellular protein synthesis, as indicated by the decrease in intensity of the background protein bands. This effect of viral infection was also inhibited by ammonium chloride. Concentrations of ammonium of 0.1 and $1 \mathrm{mM}$ had no effect on viral protein synthesis (data not shown).

An additional lysosomotropic agent, chloroquine, was also tested for its ability to inhibit viral protein synthesis. RINm5F 


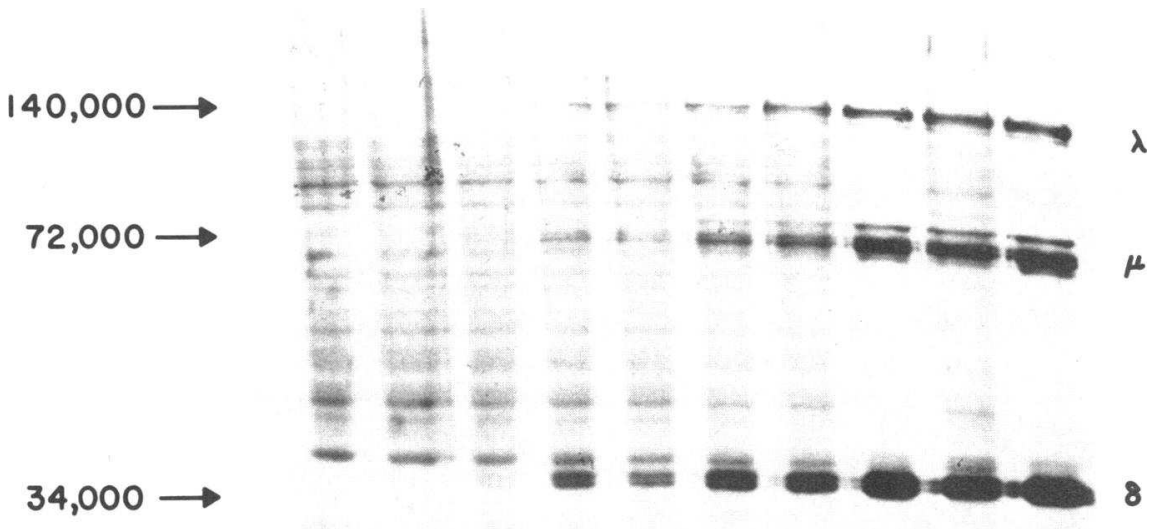

Figure 2. Cells were infected with varying input multiplicities of reovirus as indicated. 90 min after infection, growth medium with or without $10 \mathrm{mM} \mathrm{NH}_{4} \mathrm{Cl}$ was added to each well. $48 \mathrm{~h}$ after infection, cells were pulse labeled with $\left[{ }^{35} \mathrm{~S}\right]$ methionine as described in Methods. We solubilized cells in Laemmli buffer and subjected them to SDS-polyacrylamide gel electrophoresis using $10 \%$ gels.

cells were infected with $1 \mathrm{PFU} /$ cell of type 1 reovirus $48 \mathrm{~h}$ after infection. Cells were pulsed labeled with $\left[{ }^{35}\right.$ S $]$ methionine as described above. Addition of chloroquine at a concentration of 10 $\mu \mathrm{M}$ substantially inhibited labeling of all three classes of viral proteins. As assessed by densitometry, incorporation into the 3band was $85 \%$ inhibited by chloroquine (Fig. 3).

To determine the mechanism of the ammonium effect, uptake of the virus biosynthetically labeled with $\left[{ }^{35} \mathrm{~S}\right]$ methionine was directly examined in the absence and presence of $10 \mathrm{mM}$
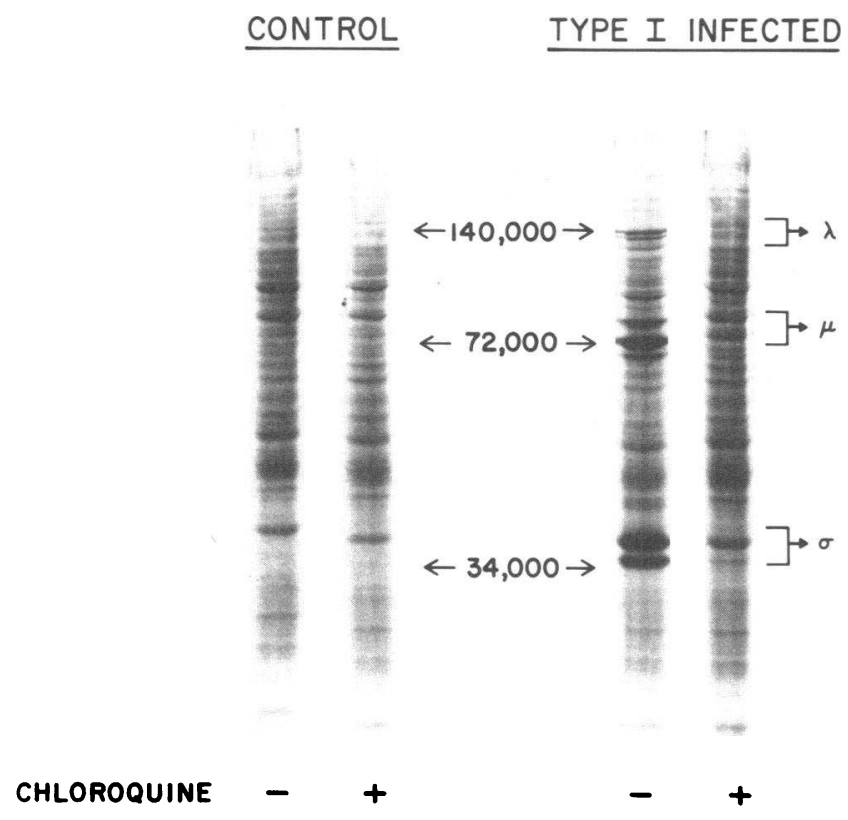

Figure 3. Type 1 reovirus at an input multiplicity of $4 \mathrm{PFU} /$ cell was added to cells as indicated. 90 min after infection, chloroquine was added to a final concentration of $10 \mu \mathrm{M} .48 \mathrm{~h}$ after infection, cells were pulse labeled with $\left[{ }^{35} \mathrm{~S}\right]$ methionine as described in Methods. Cells were solubilized in Laemmli buffer and subjected to SDS-gel electrophoresis as described in Methods.
$\mathrm{NH}_{4} \mathrm{Cl}$. In control cells, uptake of virus was continuous over a 24-h period. Viral uptake was unaffected by the presence of ammonium ion in the medium for the first $6 \mathrm{~h}$, and at later time points the ammonium-treated cells appeared to have taken up more virus than did control cells (Fig. 4).

The nature of the cell-associated virus was examined at $1 / 2$, $2,4,6$, and $24 \mathrm{~h}$ by washing the cells to remove unbound virus and then solubilizing aliquots that were subjected to polyacrylamide gel electrophoresis. Three biosynthetically labeled bands, corresponding to the three most abundant viral proteins, could be readily identified (Fig. 5). In the absence of ammonium, degradation of the band representing $\mu 1 \mathrm{c}$, one of the outer structural proteins of reovirus $\left(M_{\mathrm{r}}=72,000\right)$, was apparent by $2 \mathrm{~h}$ of infection. The degradation product, designated $\delta$, has a $M_{\mathrm{r}}$ $=65,000$. At $6 \mathrm{~h}$, in infected, nonammonium-treated cells, the ratio of $\mu 1 \mathrm{c}$ to $\sigma$ was $0.67: 1$. By contrast, the ratio was $11: 1$ in the ammonium-treated cells, which suggests that ammonium

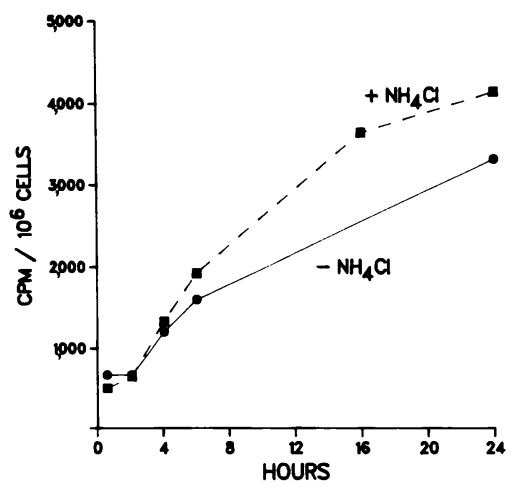

Figure 4. RINm5F cells were grown on 6-well tissues culture plates. At zero time, $\left[{ }^{35} \mathrm{~S}\right]$ methionine-labeled reovirus $(30,000 \mathrm{cpm})$ in $1.00 \mathrm{ml}$ of serum-free medium was added to each well in the absence or presence of $10 \mathrm{mM} \mathrm{NH}_{4} \mathrm{Cl}$. At designated time points, media was aspirated, cells were washed three times with PBS, and solubilized in $1 \%$ SDS. Cell-associated radioactivity was assessed by counting in a scintillation counter. 


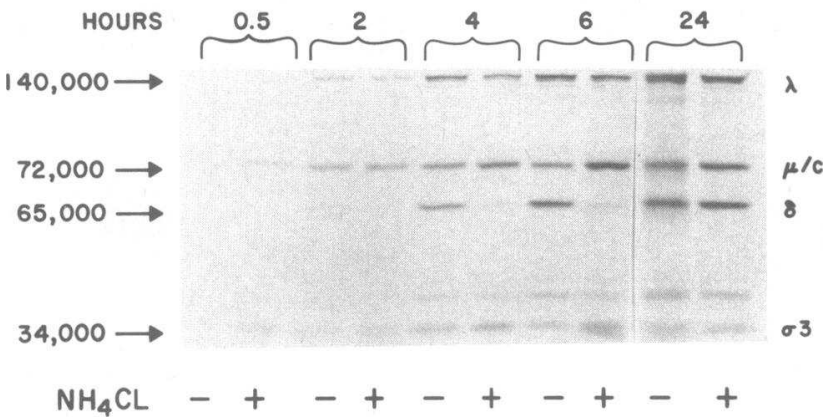

Figure 5. $\left[{ }^{35} \mathrm{~S}\right]$ Methionine-labeled virus $(30,000 \mathrm{cpm})$ added to RINm5F cells grown in 6-well plates. At designated time intervals, media was aspirated and cells washed three times with PBS. Cells were solubilized in Laemmli and subjected to SDS-polyacrylamide gel electrophoresis, which was followed by autoradiography. Radioactivity was associated with the three major capsid bands, $\lambda 2, \mu 1 \mathrm{C}$, and $\sigma 3$. Over the 24-h study period, only cleavage of $\mu 1 \mathrm{C}$ is noted.

inhibited degradation of this viral protein. At $24 \mathrm{~h}$, the relative ratio of the $\mu 1 \mathrm{c}$ and $\sigma$ bands was $0.86: 1$ in both control and ammonium-treated cells. Thus, the ability of ammonium-treated cells to degrade $\mu 1 \mathrm{c}$ was delayed, but not absolutely inhibited.

In additional experiments, ammonium was added at different points in the infectious cycle and the effect on viral titer and viral cytotoxicity were determined. As can be seen in Table I $B$, at the end of $72 \mathrm{~h}$, the maximal effect was noted when ammonium was present throughout the infectious cycle. (Addition of ammonium 90 min after infection did not differ from addition concurrent with exposure to virus.) Less effect on viral titer and cell viability were noted when ammonium was added only for

Table I A. Effect of $\mathrm{NH}_{4} \mathrm{Cl}$ on Viral Titer

\begin{tabular}{|c|c|c|}
\hline \multirow{2}{*}{$\begin{array}{l}\text { Experiment } \\
\text { (No.) }\end{array}$} & \multicolumn{2}{|l|}{ Viral titer } \\
\hline & Ammonium (+) & Ammonium (-) \\
\hline 1 & $1.5 \times 10^{5} \pm 0.71 \times 10^{5}$ & $1.5 \times 10^{6} \pm 0.01 \times 10^{6}$ \\
\hline 2 & $1.6 \times 10^{6}$ & $18 \times 10^{6}$ \\
\hline 3 & $8.25 \times 10^{6} \pm 0.35 \times 10^{6}$ & $15.3 \times 10^{6} \pm 2.4 \times 10^{6}$ \\
\hline
\end{tabular}

B. Time Dependence of $\mathrm{NH}_{4} \mathrm{Cl}$ Effect

\begin{tabular}{|c|c|c|c|c|}
\hline \multicolumn{2}{|c|}{$\begin{array}{l}\text { Ammonium } \\
\text { treatment }\end{array}$} & \multirow[b]{2}{*}{ Viral titer } & \multirow{2}{*}{$\begin{array}{l}\text { Viral titer } \\
\text { (\% nonammonium } \\
\text { treated) }\end{array}$} & \multirow{2}{*}{$\begin{array}{l}\text { Protein/well } \\
\text { (\% uninfected } \\
\text { control) }\end{array}$} \\
\hline $1-24 h$ & 24-78 h & & & \\
\hline+ & + & $6.0 \times 10^{6} \pm 2.2 \times 10^{6}$ & 30 & 91 \\
\hline+ & - & $11.5 \times 10^{6} \pm 3.8 \times 10^{5}$ & 58 & 78 \\
\hline- & + & $15.5 \times 10^{6} \pm 4.0 \times 10^{5}$ & 76 & 52 \\
\hline- & - & $19.8 \times 10^{6} \pm 7.5 \times 10^{5}$ & 100 & 36 \\
\hline
\end{tabular}

(A) In exp. 1, cells were infected with 1 PFU/cell. In exps. 2 and 3, cells were infected with $5 \mathrm{PFU} /$ cell. $10 \mathrm{mM}$ ammonium chloride was added as indicated. Viral titer, $48 \mathrm{~h}$ after injection, is reported as the mean of duplicate wells + or - range. $(B)$ Cells were infected with an input multiplicity of $5 \mathrm{PFU} / \mathrm{cell}$ and $10 \mathrm{mM}$ ammonium chloride was added as indicated. After the first $24 \mathrm{~h}$, cells were washed three times with PBS, and fresh media with or without ammonium was added for the subsequent $48 \mathrm{~h}$. Viral titer is reported as the mean of duplicate wells + or - range. the first $24 \mathrm{~h}$ after infection, and there was even less of an effect if ammonium was added after $24 \mathrm{~h}$ of infection.

\section{Discussion}

Endocytosis is the mechanism by which a wide variety of ligands including hormones (21), proteins (22), lipoproteins (23), and toxins (24) may enter cells. When this process involves the binding of ligand to a specific membrane receptor it has been termed "receptor-mediated" endocytosis. After binding, the ligand is internalized via an endocytic vesicle that may or may not be clathrin coated. Subsequently, some endocytic vesicles fuse with lysosomes or become associated with golgilike structures. The endocytic process is also important for viral entry. Since not all viruses are known to interact with specific plasma membrane receptors, the term "adsorptive endocytosis" has been applied to viral entry. In the case of enveloped viruses, such as Semliki Forest virus and influenza virus, this process has been extensively studied $(1-3,25)$. After internalization, the endocytic vesicle forms a secondary lysosome. The low $\mathrm{pH}$ in the secondary lysosome is essential to viral penetration, since it allows the virus envelope to fuse with the interior of the vesicular membrane and thereby release the viral core contents into the cytoplasm.

More recently, successful viral infection with certain nonenveloped viruses such as foot-and-mouth-disease virus (26) and poliovirus (27) has been shown to be dependent on endocytosis and lysosomal processing, and growth of these viruses has been shown to be inhibited by lysosomotropic agents.

Reovirus has also been found to be associated with lysosomal structures (28), and this association may be important in the uncoating of parental virus and in the formation of SVPs. However, the biochemical steps occurring in the lysosomes and the mechanism of release of the SVPs from the lysosomes are unknown. SVPs have lost the $\mu 1 \mathrm{C}$ protein and possess an active RNA-dependent RNA transcriptase $(29,30)$. Genetic studies suggest that the activation of the transcriptase is dependent on cleavage of the $\mu 1 \mathrm{C}(31,32)$, and all SVPs with an active transcriptase have at least a portion of their $\mu 1 \mathrm{C}$ proteins cleaved $(33,34)$.

Our data demonstrate that lysosomotropic agents inhibit the growth of reovirus and also significantly inhibit synthesis of viral proteins. This effect is seen over a range of infecting doses from 0.4 to $10 \mathrm{PFU} /$ cell. Inhibition of viral growth is associated with enhanced viability of infected cells and improved cellular function as assessed by overall macromolecular synthesis. $\mathrm{NH}_{4} \mathrm{Cl}$ does not inhibit uptake of reovirus. However, cleavage of $\mu 1 \mathrm{C}$ is inhibited by $\mathrm{NH}_{4} \mathrm{Cl}$. This suggests that lysosomal cleavage of $\mu 1 C$ is a critical step in the activation of the reovirus SVPs, and that inhibition of this process by lysosomotropic agents can lead to an overall inhibition of both viral growth and the effects of viral infection. Interestingly, the other major protein components of reovirus, $\lambda 2$ and $\sigma 3$, were not degraded over the 24 -h period of incubation.

In summary, the findings in this study suggest that the lysosome is as important in the processing of some nonenveloped viruses as it is with enveloped viruses. In the case of reovirus, lysosomal processing is associated with the cleavage and presumed activation of a specific capsid protein. Delaying viral processing via the addition of lysosomotropic agents reduces viral cytotoxicity. Further studies will be required to determine whether such effects might be seen in the intact animal. However, such finding might provide a strategy for treatment of certain viral infections in man and other animals. 


\section{Acknowledgments}

We would like to thank Terri-Lyn Bellman for her excellent secretarial support.

This work was supported in part by a Feasibility Grant from the American Diabetes Association. Dr. Eleftheria Maratos-Flier is a recipient of a National Institutes of Health Clinical Investigator's Award.

\section{References}

1. Helenius, A., J. Kartenbeck, K. Simons, and E. Fries. 1980. On the entry of Semliki Forest virus into BHK-21 cells. J. Cell Biol. 84:404420.

2. Marsh, M., and A. Helenius. 1980. Adsorptive endocytosis of Semliki Forest virus. J. Mol. Biol. 142:439-454.

3. Helenius, A., M. Marsh, and J. White. 1982. Inhibition of Semliki Forest virus penetration by lysosomotropic weak bases. J. Gen. Virol. 58:47-61.

4. Braunwald, J., H. Nonnemacher, and F. Tripier-Darcy. 1985. Ultrastructural and biochemical study of frog virus 3 uptake by BHK-21 cells. J. Gen. Virol. 66:283-293.

5. Ohkuma, S., and B. Poole. 1978. Fluorescence probe measurement of the intralysosomal $\mathrm{pH}$ in living cells and the pertubation of $\mathrm{pH}$ by various agents. Proc. Natl. Acad. Sci. USA. 75:3327-3333.

6. Yamashiro, D. J., and F. R. Maxfield. 1984. Acidification of endocytic compartments and the intracellular pathways of ligands and receptors. J. Cell Biochem. 26:231-246.

7. Canning, W. M., and B. N. Fields. 1983. Ammonium chloride prevents lytic growth of Reovirus and helps to establish persistent infection in mouse L cells. Science (Wash. DC). 219:987-988.

8. Sharpe, A. H., and B. N. Fields. 1983. Pathogenesis of reovirus infection. In The Reoviridae. Plenum Publishing Corp., New York and London. 229-285.

9. Weiner, H. L., D. Drayna, D. R. Averill, and B. N. Fields. 1977. Molecular basis of reovirus virulence: role of the S1 gene. Proc. Natl. Acad. Sci. USA. 74:5744-5758.

10. Weiner, H. L., M. L. Powers, and B. N. Fields. 1980. Absolute linkage of virulence and central nervous system cell tropism of reovirus to viral hemagglutinin. J. Infect. Dis. 141:609-616.

11. Onodera, T., A. B. Jenson, J. W. Yoon, and A. L. Notkins. 1978. Virus-induced diabetes mellitus: reovirus infection of pancreatic beta cells in mice. Science (Wash. DC). 201:529-531.

12. Haspel, M. W., T. Onodera, S. Prabhakar, M. Horita, H. Suzuki, and A. L. Notkins. 1983. Virus induced autoimmunity: monoclonal antibodies that react with endocrine tissues. Science (Wash. DC). 220: 304-306.

13. Yoon, J. W., S. Selvaggio, T. Onodera, J. Wheeler, and A. B. Jenson. 1981. Infection of cultured human pancreatic $B$ cells with reovirus type 3. Diabetologia. 20:462-467.

14. Onodera, T., A. Toniolo, U. R. Ray, A. B. Jenson, and R. A. Knazek. 1981. Virus-induced diabetes mellitus. XX. Polyendocrinopathy and autoimmunity. J. Exp. Med. 153:1457-1473.

15. Gazdar, A. F., W. L. Chick, H. K. Oie, H. L. Sims, D. L. King, G. C. Weir, and V. Lauris. 1980. Continuous, clonal, insulin and so- matostatin secreting cell lines established from a transplantable rat islet cell tumor. Proc. Natl. Acad. Sci. USA. 77:3519-3523.

16. Praz, G. A., P. A. Halban, C. B. Wollheim, B. Blondel, A. J. Strauss, and A. E. Renold. 1983. Regulation of immunoreactive-insulin release from a rat cell line (RINm5F). Biochem J. 210:345-352.

17. Maratos-Flier, E., M. J. Goodman, B. N. Fields, and C. R. Kahn. 1985. Differential effects of viral infection on islet and pituitary cell lines. Endocrinology. 116:2430-2437.

18. Ramig, R. F., R. K. Cross, and B. N. Fields. 1977. Genome RNAs and polypeptides of reovirus serotypes 1, 2 and 3. J. Virol. 22: 726-733.

19. Sharpe, A. H., and B. N. Fields. 1982. Reovirus inhibition of cellular RNA and protein synthesis: role of the S4 gene. Virology. 122: 381-391.

20. Laemmli, U. K. 1970. Cleavage of structural proteins during the assembly of the head of bacteriophage T4 Nature (Lond.). 227:680-685.

21. Maxfield, F. R., J. Schlessinger, Y. Schecter, I. Pastan, and M. C. Willingham. 1978. Collection of insulin, EGF and alpha2-macroglobulin in the same patches on the surface of cultured fibroblasts and common internalization. Cell. 14:805-810.

22. Ashwell, F., and J. Harford. 1982. Carbohydrate-specific receptors of the liver. Ann. Rev. Biochem. 51:531-554.

23. Brown, M. S., P. T. Kovanen, and J. L. Goldstein. 212. Regulation of plasma cholesterol by lipoprotein receptors. Science (Wash. DC). 628: 1981.

24. Sandvig, K., and S. Olsnes. 1980. Diptheria toxin entry into cells is facilitated by low pH. J. Cell Biol. 87:828-832.

25. Yoshimura, A., and S. I. Ohnishi. 1984. Uncoating of influenza virus in endosomes. J. Virol. 51:497-504.

26. Carrillo, E. C., C. Giachetti, and R. H. Campos. 1984. Effect of lysosomotropic agents on the foot and mouth disease virus replication. Virology. 135:542-545.

27. Zeichhardt, H., K. Wetz, P. Willingmann, and K. O. Habermehl. 1985. Entry of poliovirus type 1 and mouse elberfeld (ME) virus into HEp-2 cells: receptor-mediated endocytosis and endosomal or lysosomal uncoating. J. Gen. Virol. 66:483-492.

28. Silverstein, S. C., and S. Dales. 1968. The penetration of reovirus RNA and initiation of its genetic function in L-strain fibroblasts. J. Cell Biol. 36:197-230.

29. Borsa, J., and A. F. Graham, 1968. Reovirus: RNA polymerase activity in purified virions. Biochem. Biophys. Res. Commun. 33:895901.

30. Shatkin, A. J., and J. D. Sipe. 1968. RNA polymerase activity in purified reoviruses. Proc. Natl. Acad. Sci. USA. 61:1462-1469.

31. Joklik, W. K. 1972. Studies on the effect of chymotrypsin on reovirions. Virology. 49:700-715.

32. Drayna, D., and B. N. Fields. 1982. Activation and characterization of the reovirus transcriptase: genetic analysis. J. Virol. 41:110118.

33. Chang, C. T., and H. J. Zweerink. 1971. Fate of parental reovirus in infected cell. Virology. 46:544-555.

34. Shatkin, A. J., and A. J. LaFiandra. 1972. Transcription by infectious subviral particles of reovirus. J. Virol. 10:698-706. 